\title{
Epigenetics and the germline
}

\author{
Cinzia Allegrucci, Alexandra Thurston, Emma Lucas and Lorraine Young \\ Division of Obstetrics and Gynaecology and Institute of Genetics, University of Nottingham, \\ Queens Medical Centre, Nottingham NG7 2UH, UK \\ Correspondence should be addressed to L Young; Email: lorraine.young@nottingham.ac.uk
}

\begin{abstract}
Epigenetic processes affect three stages of germline development, namely (1) specification and formation of primordial germ cells and their germline derivatives through lineage-specific epigenetic modifications, in the same manner as other embryonic lineages are formed, (2) a largely genome-wide erasure and re-establishment of germline-specific epigenetic modifications that only occurs in the embryonic primordial germ cell lineage, followed by re-establishment of sex-specific patterns during gametogenesis, and (3) differential epigenetic modifications to the mature male and female gamete genomes shortly after fertilisation. This review will detail current knowledge of these three processes both at the genome-wide level and at specific imprinted loci. The consequences of epigenetic perturbation are discussed and new in vitro models which may allow further understanding of a difficult developmental period to study, especially in the human, are highlighted.
\end{abstract}

Reproduction (2005) 129 137-149

\section{Epigenesis}

In terms of regulation of gene expression in the germline, epigenesis can be defined as 'alterations in DNA function without alterations in DNA sequence' (Jones \& Takai 2001). In somatic cells, DNA exists in a nucleosomal form, with chromatin formed in conjunction with core and linker histones ( $\mathrm{Li}$ 2002). The complex pattern of silenced/expressed gene regions that exists within the genome of a single cell type is tightly regulated by epigenetic modifications, either to the histones or to the DNA itself (Felsenfeld \& Groudine 2003, Jaenisch \& Bird 2003). Although the exact ontogeny of events remains controversial (Li 2002), it is likely that when regions of active chromatin are silenced, histone deacetylases remove acetylation from the histones. If the genome is to be permanently silenced in this region (rather than just transiently, e.g. during the cell cycle), then methyl groups are transferred to cytosine residues present in a CpG base pair configuration through the action of the de novo methyltransferases, DNMT3a and 3b. During subsequent cellular generations, this methylation is faithfully recapitulated by the action of the maintenance methyltransferase, DNMT1 (Li 2002). The linking of DNA methylation and histone deacetylation in specific genomic regions appears to confer a powerful mechanism for long-term gene silencing (Meehan et al. 2001, Bird 2002, Sutherland \& Costa 2003). It is emerging that the trigger for de novo methylation of DNA involves a series of histone modifications other than deacetylation, with methylation of histone $\mathrm{H} 3$ at the lysine 9 position (H3-K9) strongly correlating with DNA methylation (Felsenfeld \& Groudine 2003, Jaenisch \& Bird 2003).

There are several consequences of the epigenetic methylation of DNA. One of the major functions of DNA methylation appears to be to permanently silence the large proportion of 'junk' DNA, repetitive sequences that have entered our genomes throughout the course of evolution, mainly by viral transfection (Jaenisch 1997, Yoder et al. 1997). Forty-five percent of the human genome consists of viral retrotranposons and endogenous retroviruses (Lander et al. 2001), repeat sequences that are capable of moving around the genome and/or causing instability and inappropriate expression of local genes if not kept in check by strong silencing mechanisms. The highly abundant Satellite repeat sequences are permanently located in the hypermethylated centromeric heterochromatin regions, while there are many dispersed repeats that exist within the more active euchromatic regions. The complex epigenetic regulation of gene expression is also thought to have been an evolutionary prerequisite to multicellularity (Jablonka \& Lamb 1998), allowing development of lineage-specific gene expression patterns within organisms whose cells all contain the same genetic code. Thus, as each new lineage forms within the developing embryo, a unique pattern of silenced/expressed regions is set up (Bird 2002, Shiota et al. 2002). 


\section{Formation of the germline}

\section{Mouse}

Until recently, it was considered that the germline of mammals was not a consequence of this epigenetic developmental process but that, like several lower organisms, a subset of the oocyte cytoplasm known as the germplasm was already set-aside to form the germ cells prior to fertilisation (reviewed by Johnson et al. 2003a,b). In fact, cell fate mapping revealed the origin of primordial germ cells (PGCs) in mouse to be in the proximal epiblast of the embryo (Lawson \& Hage 1994), with germ cell competence induced by bone morphogenetic protein (BMP)4 from the extraembryonic endoderm (Saitou et al. 2002). At 6.25 days post-coitum (dpc), this BMP4 induction primes the proximal epiblast to become interferon responsive (Lange et al. 2003) and interferon induces fragilis gene expression, defining the portion of embryonic mesoderm with germ cell competence (Saitou et al. 2002). At $7.0 \mathrm{dpc}$, PGCs arise from a population of around 100 cells (Ginsburg et al. 1990) and a subset of high-fragilis expressing cells then induce stella, the product of which represses the homeobox gene expression pathway that would induce somatic cells such as those of the haematopoietic system and instead restricts a germ cell fate (Saitou et al. 2002). By $8.0 \mathrm{dpc}$ the PGCs are distinct at the base of the allantois (Nagy et al. 2003) and then migrate to the embryonic hindgut (Tam \& Snow 1981). By $8.5 \mathrm{dpc}$, they further migrate through the embryonic mesentery, linking through E-cadherin- (Bendel-Stenzel et al. 2000) and $\beta 1$ integrin (Anderson et al. 1999)-mediated cellular processes before arriving at the gonadal ridge at $11.5 \mathrm{dpc}$. During the migratory period the PGCs begin to proliferate, completing formation of around 50000 cells by two days after entry into the gonadal ridge (Donovan et al. 1986, Nagy et al. 2003). PGC proliferation during migration and before reaching the gonadal ridge is controlled by stem cell factor (SCF), c-Kit receptor tyrosine kinase and c-Kit ligand (Readhead \& Muller-Tidow 2002). PGCs in the gonadal ridge express vasa and dazl (Noce et al. 2001, Saunders et al. 2003), they become non-motile and then enter first meiotic prophase (female gonocytes) or mitotic arrest (male gonocytes). The default pathway in mammalian gonadal ridges is to form an ovary; only when expression of the sry gene is initiated from a $\mathrm{Y}$ chromosome will the testis-specific pattern of gene expression be initiated (Knower et al. 2003). A range of factors, including Gas-6, Gata-4, Zfx (females), Zfy (males), SF-1 and Wt-1 are involved in the differentiation of PGCs into male or female gonocytes depending on the $\mathrm{XX}$ or $\mathrm{XY}$ composition of the embryo and male-specific expression of sry (Knower et al. 2003). It is not until the onset of puberty that meiosis l-arrested female gonocytes and mitosisarrested male gonocytes continue division and become haploid (Picton et al. 1998, Donovan \& de Miguel 2003).

\section{Human}

Due to obvious difficulties and ethical restrictions in obtaining experimental material, much less is known regarding the gene expression patterns regulating germ cell fate in humans. Sadler (2004) recently reported that human PGCs are formed in the epiblast during week 2 of development. At week 4, the cells begin to migrate from the yolk sac towards the presumptive gonads (Goto et al. 1999, Larsen 2001, Sadler 2004). By the end of week 5, the PGCs arrive in the gonadal ridge (Sadler 2004) and by 10 weeks, female germ cells have entered meiosis while male germ cells continue mitosis until 16-18 weeks of gestation (Goto et al. 1999). In both sexes, mature germ cells are not formed until puberty, as in the mouse.

\section{Epigenetic changes associated with germline specification}

After fertilisation, the genomes inherited from both sperm and oocytes undergo a cycle of erasure of most of their associated DNA methylation, with lineage-specific patterns of de novo methylation occurring during or after gastrulation. Like other newly-formed lineages, primordial germ cells also undergo this phase of de novo methylation (Hajkova et al. 2002).

While the epigenetic regulation of this germline specification programme in specific genes has not yet been examined, evidence for specific epigenetic modifications of germline genes has surprisingly come from the study of a variety of adult tumours. Loriot et al. (2003) identified a number of germline genes that were aberrantly reactivated in tumours and demonstrated that reactivation was associated with demethylation of the promoter regions. Interestingly, many of these genes were specifically expressed in spermatogonia, the testis stem cells, rather than any later gamete stages. When lymphoid cell lines were treated in vitro with the DNA methylation inhibitor 5-azadeoxycytidine, these spermatogonial genes could also be reactivated in vitro.

More recently, both the oct4 (Gidekel \& Bergman 2002, Hattori et al. 2004) and sry (Nishino et al. 2004) genes involved in germ cell pluripotency and gonadal sex determination respectively, have been shown to have their temporal and tissue-specific patterns of gene expression regulated by DNA methylation, with regulatory regions of these genes undergoing a brief period of demethylation concurrent with gene expression. The methylation status of PGC specification genes such as fragilis and stella is not known; however their temporally restricted expression might predict regulation by DNA methylation/demethylation as in sry and oct4. A homologue of stella has recently been described in the human genome (Payer et al. 2003) that is also expressed in human oocytes (Goto et al. 2002), suggesting conservation of function.

The epigenetic regulation of spermatogenesis at least is beginning to be investigated, with mice null for Dnmt3a, 
Dnmt3I and histone methyltransferases all disrupting various phases of meiosis (Li 2002). Between the preleptotene and pachytene stages of spermatogenesis, there appears to be a coupling of histone H3-K9 methylation and histone deacetylation which has been suggested to suppress global gene expression when spermatocytes are undergoing meiosis (Li 2002).

\section{Germline epigenetic reprogramming}

In addition to requiring epigenetic modifications to form the germline, the PGCs uniquely undergo an extra and very dramatic wave of epigenetic reprogramming that most other lineages do not undergo. This process is thought to be essential for the generation of new cells that will allow totipotency in the preimplantation embryo, for ensuring that both sexes acquire an equivalent epigenetic state prior to the differentiation of sex-specific gametes and imprints (see below) and to allow erasure of epimutations that adult cells (presumably including gametes) can inherit during their lifetime. It is of obvious evolutionary advantage to remove such errors in the germline prior to forming a new generation. Although aberrant inheritance of epimutations is known to occur in plants, recent studies in mice suggest that this phenomenon may also occur in mammals and may underlie the inheritance of some disease phenotypes or susceptibility (Rakyan et al. 2001, 2003).

\section{Reprogramming of non-imprinted genes}

Within one day of entering the genital ridge, both male and female mouse PGCs actively erase their methylation component in a number of sequences (Hajkova et al. 2002). By $12.5 \mathrm{dpc}$, methylation of the single copy genes alpha actin and mylc are erased and it is assumed that this is representative of other single copy sequences in the genome. Of interest, however, is that some repetitive elements do not entirely erase their methylation prior to mitotic/meiotic arrest (Walsh et al. 1998, Hajkova et al. 2002), while others undergo substantial demethylation (Lane et al. 2003).

Within the gonad, sex-specific epigenetic patterns are then re-established at different developmental stages (Hajkova et al. 2002). In the male mouse, remethylation begins before birth $(15.5-18.5 \mathrm{dpc})$ in prospermatogonia and is completed prior to the end of meiotic pachytene after birth. Using an antibody raised against 5-methylcytosine, the $15.5 \mathrm{dpc}$ testis showed no genome-wide labelling of methylated DNA in the gonocytes, only in the somatic Sertoli cells, whereas by $18 \mathrm{dpc}$ spermatogonia were also labelled (Coffigny et al. 1999). This study observed that male germ cells always possess hypomethylated heterochromatin relative to somatic cells, whereas their euchromatin passes from a demethylated to a strongly methylated status between days 16 and 17 postcoitum. This is consistent with the relative undermethylation of centromeric Satellite DNA in germ cells (Ponzetto-Zimmermann \&
Wolgemuth 1984, Sanford et al. 1984), although the significance of this is not yet understood. In the mouse, even in mature gametes, the pattern of methylation is germline specific so that sperm DNA is globally hypermethylated compared with oocyte DNA, but both gametes are hypomethylated relative to somatic tissues (reviewed by Constancia et al. 1998). Recently, a study of $1500 \mathrm{CpG}$ island regions, associated with gene promoters, found that 30 methylated loci detected in mature spermatozoa were not detected in embryonic germ (EG) cells, indicating widespread epigenetic change associated with germline differentiation (Shiota et al. 2002). Sixty-six percent of the gene-associated regions analysed were unmethylated, suggesting that the global hypermethylation previously reported in sperm may be due to abundant repeat sequences and do not reflect the majority of PGC genes. However, artefactual results arising from derivation or culture of EG cells compared with PGCs cannot be ruled out.

Remethylation of the female germline has not been examined at the global level and so information on the timing of this process is largely only available for imprinted genes as discussed below. However, it is known that both growing and mature mouse oocytes have lower Satellite and dispersed repeat methylation than sperm or somatic cells (Monk et al. 1987, Sanford et al. 1987, Howlett \& Reik 1991).

\section{Reprogramming of genomic imprints}

Imprinted genes comprise a small subset of the genome (perhaps 100 out of the total 30000 genes (Miozzo \& Simoni 2002) whose epigenetic reprogramming in the germline is imperative for subsequent normal development of the embryo. Genomic imprinting is the phenomenon that gives rise to differential expression of paternally and maternally inherited alleles of certain genes due to sex-specific epigenetic differences inherited from the germline. Thus, unlike most genes in our genome, which are either expressed or silenced from both parentally inherited alleles (biallelic expression), monoallelic expression of imprinted genes occurs in a tissue- and developmental stage-specific manner during development (Lyle 1997, Miozzo \& Simoni 2002). Genomic imprinting has been reported in several mammalian species humans, mouse, rat, sheep, marsupials etc (Miozzo \& Simoni 2002 and see http://cancer.otago.ac.nz:8000/table. html) with monoallelic expression appearing restricted to the embryonic and fetal periods. Those imprinted gene loci that express in post-natal tissues invariably show biallelic expression (Moore 2001, Reik \& Dean 2001). Since monoallelic expression affects the dosage of the mRNA and resulting protein, the effect of the imprinting process is to limit the effect of the gene product.

The monoallelic expression of imprinted genes involves significant differences in allelic chromatin conformation due to differential DNA methylation of cytosine residues, phosphorylation, histone acetylation and methylation of 
histone proteins as well as the modification and assembly of regulatory protein complexes on DNA (Meehan 2003). These imprinted differences between the egg and sperm are then transmitted to the somatic cell lineages that form after fertilisation.

In the germline, DNA methylation is so far the most widely studied epigenetic process associated with genomic imprinting, although whether it represents the primary 'imprint' distinguishing the parental alleles is currently under debate. Differential methylation arises in specific gene regions known as differentially methylated regions or DMRs. Two types of DMRs are known: primary DMRs comprising DNA sequences methylated differentially in oocytes, and sperm and secondary DMRs that form after fertilisation. Allele-specific methylation patterns are considered to be established and maintained due to the presence of repetitive sequence regions near DMRs (Constancia et al. 1998, Lucifero et al. 2004). The restriction of de novo methylation to specific imprinted genes in the developing germline is thought to involve the CCCTCbinding factor (CTCF) boundary element (Fedoriw et al. 2004). When the zinc finger CTCF protein binds to its target binding site in imprinted genes (if the site is unmethylated), the complex acts to partition the genome into active or inactive chromatin domains (Burgess-Beusse et al. 2002) and to prevent further recruitment of DNA methylation and aberrant silencing of neighbouring regions. RNA interference-induced deficiency of CTCF resulted in an increase in methylation at the H19 DMR region and a decrease in development competence of the oocytes. Thus CTCF appears to protect the maternal DMR (at least for H19) from de novo methylation during oocyte growth (Fedoriw et al. 2004). A male germline-specific homologue of CTCF, BORIS, is discussed below.

The allelic methylation of imprinted genes appears to occur through a unique combination of methyltransferase enzymes, and methylation coincides with the presence of high levels of DNA methyltransferases in the oocyte nucleus (Constancia et al. 1998, Lucifero et al. 2004). Dnmt3l is similar to the de novo methyltransferases, Dnmt $3 a$ and $3 b$, in many structural domains except that it lacks methylation catalytic activity. Dnmt3I interacts and colocalises with Dnmt3a to modulate de novo methylation of imprinted genes in the female gamete (Chedin et al. 2002, Hata et al. 2002). Male mice null for Dnmt3/ produce spermatogonia unable to undergo differentiation and meiosis while female mutant mice were unable to methylate sequences that are normally methylated maternally (Bourc'his et al. 2001b). The effect of lack of Dnmt3/ was specific to imprinted regions, with global genome methylation levels unaffected. The lack of maternal methylation imprints resulted in biallelic expression of genes that are normally only paternally expressed (Bourc'his et al. 2001b). Dnmt1o is the oocyte-specific form of Dnmt1, involved in methylation of maternal imprints in the 8-cell stage mouse embryo (Doherty et al. 2002).
It has also been suggested that different chromatin regulatory factors are present in the two forming germlines, that might promote different chromatin organisations which are either conducive to or inhibit DNA methylation (Feil \& Khosla 1999, Lucifero et al. 2004). Paulsen and Ferguson-Smith (2001) report that DMRs do not necessarily retain a methylation pattern acquired during gametogenesis and Igf2 and H19 DMRs do not represent primary imprints (Olek \& Walter 1997, Oswald et al. 2000). It appears that although methylation imprints are erased in PGCs, other epigenetic regulation factors may not be and it may be these factors that direct DNA methylation exclusively. While sex-specific forms of Dnmt1 have been described (Mertineit et al. 1998, Pradhan \& Esteve 2003), other germline-specific epigenetic or chromatin remodelling factors have not been identified. However, clues to potential regulators may arise from the study of differential modifiers of the male and female pronuclei in the zygote, where sex-specific differences in binding of heterochromatin protein 1 (HP1) and histone $\mathrm{H} 3-\mathrm{K} 9$ methylation have been established (Arney et al. 2002, Cowell et al. 2002).

Support for the functional importance of methylation during oocyte growth comes from nuclear transplantation studies where parthenogenetic embryos containing one genome from neonate-derived non-growing oocytes (with no female imprints, thus mimicking a male genome) and the other from a fully grown oocyte (with fully developed female imprints) develop for a longer period than do normal parthenogenetic samples (Kono et al. 1996, Obata et al. 1998). Definitive proof that it is the lack of complete imprinting that is the cause of developmental failure in these embryos seemed to be provided recently from a study where deleting $\mathrm{H} 19$ in the non-growing oocytes (restoring normal expression of the imprinted fetal mitogen, Igf2) allowed full-term survival of a single non-growing/fully grown oocyte pronuclear hybrid (Kono et al. 2004). However, until this is repeated and demonstrated not to be just a chance event, the significance of the parthenogenetic birth is still unclear (Moore \& Ball 2004).

\section{Imprinting inheritance}

Since epigenetic imprints are fully established in the embryo by the time of gastrulation (Reik et al. 2001), all subsequent cell lineages, including PGCs, will contain imprinted loci that are differentially marked on both alleles. Thus, when germ cells undergo meiosis and become haploid, this 'imprint' must be able to be erased and reversed so it can be transmitted to the next generation in a sexspecific manner (Fig. 1). If this process did not occur, half of all sperm (or oocytes) ultimately formed within an individual could potentially have the wrong parental imprint, risking the production of all female (parthenogenetic) or all male (androgenetic) embryos at fertilisation (Fig. 2). Studies on parthenogenetic mice (Surani et al. 1984, Kono et al. 1996) and sheep (Feil et al. 1998, Hagemann et al. 1998), 


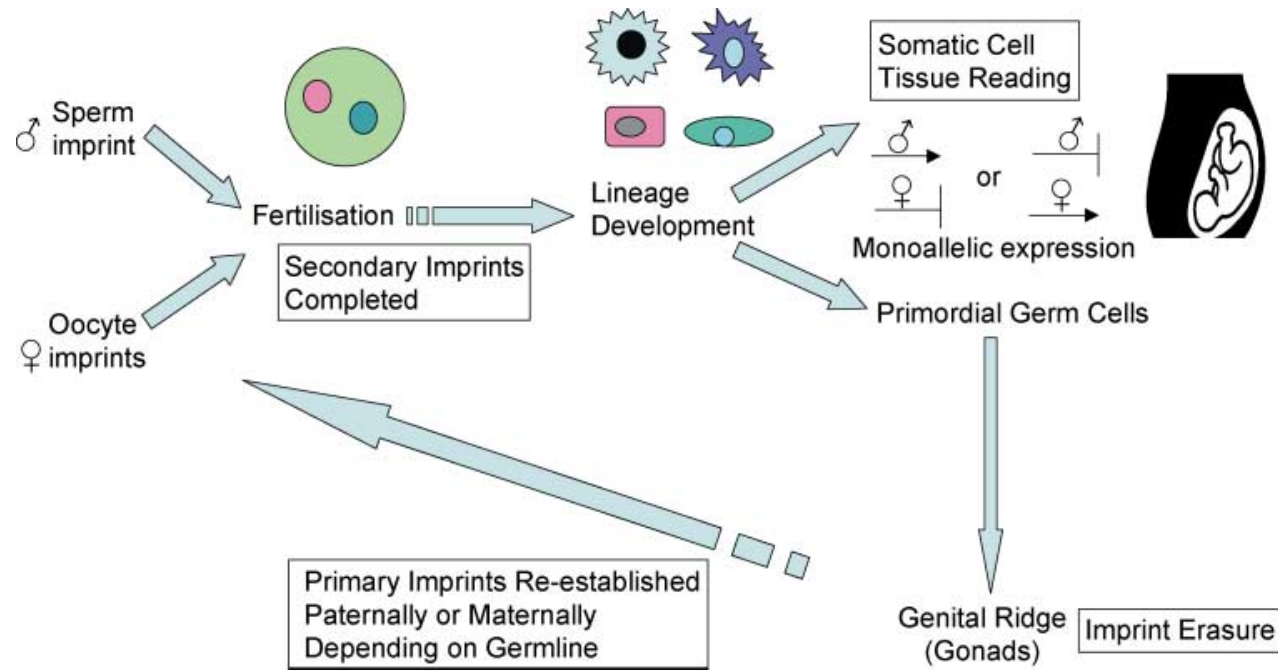

Figure 1 The imprinting inheritance cycle. Primary imprints distinguishing parental alleles are established during gametogenesis, such that mature sperm and oocytes are differentially marked. After fertilisation, imprints are further modified to allow monoallelic expression in the fetal lineages, where imprints are read. This results in monoallelic expression in a gene-, tissue- and developmental stage-specific manner. In the primordial germ cell lineage, inherited imprints are erased shortly after entry to the gonadal ridge, then re-established at different stages of development of the male and female gametes, completing the cycle. both of which die in early/mid gestation, have shown that correctly established imprints from both sexes are required for normal fetal development.

\section{Erasure of imprints}

Several studies have now demonstrated that the erasure of at least methylation imprints occurs in the germline shortly after the PGCs enter the gonadal ridge. PGCs migrating to the genital ridge around $9.5-10.5 \mathrm{dpc}$ are reported to have the allele-specific imprints characteristic

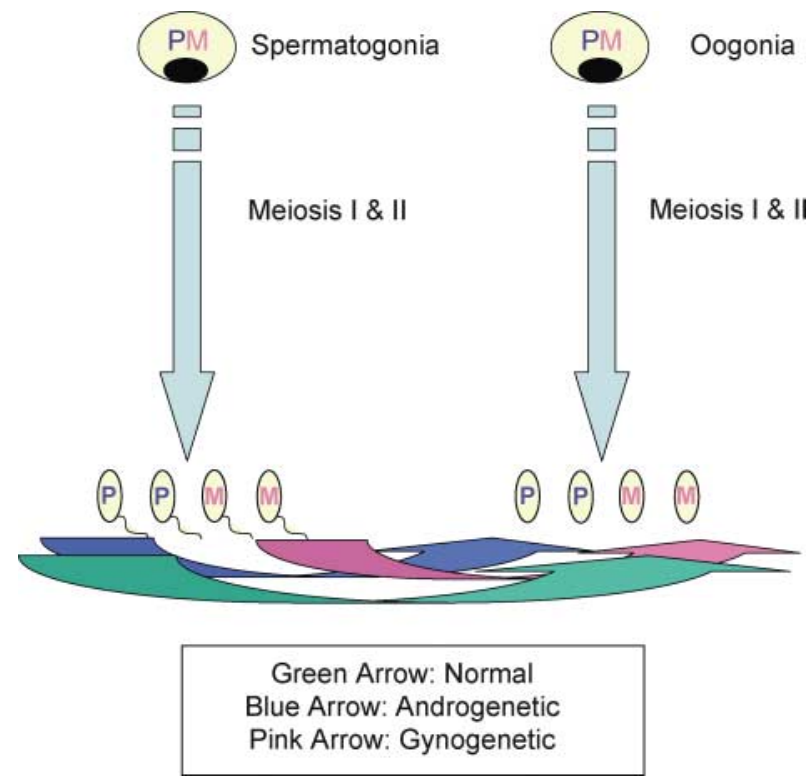

Figure 2 Importance of imprinting erasure. This fig. demonstrates the possible developmental outcomes without imprinting erasure. Neither parthenogenetic or androgenetic embryos are capable of survival to term, demonstrating the developmental importance of correct genomic imprinting. Green arrow, normal embryo; blue arrow, androgenetic embryo; pink arrow, parthenogenetic embryo. P, paternal; $M$, maternal. of other somatic lineages at this time (Ueda et al. 2000, Surani 2001), although at least some erasure of imprints may already be initiated by $10.5 \mathrm{dpc}$ (Yamazaki et al. 2003). In support of this, Igf $2 r$ transgenic mice expressing green fluorescent protein specifically in the germline begin to demethylate some CpG sites within DMR2 at $9.5 \mathrm{dpc}$ in some migrating PGCs before the cells colonize genital ridges (Sato et al. 2003). However, progression of Igf2 $r$ demethylation is more rapid after colonization of the genital ridges. Within a day of entering the genital ridge $(10.5-11.5 \mathrm{dpc})$, analysis of a range of imprinted genes has revealed that erasure is completed and is maintained until at least $13.5 \mathrm{dpc}$ (Kafri et al. 1992, Hajkova et al. 2002, Yamazaki et al. 2003).

\section{Re-establishing imprints in the female}

After erasure of germline methylation imprints, differentiating germ cell genomes must become maternalised or paternalised depending on germ cell sex, and this must occur before the onset of meiosis. In the female germline, imprints are re-established in growing oocytes. Various imprinted genes receive an 'imprinting mark' asynchronously at particular stages during oocyte meiotic prophase I, during the primordial to antral follicle transition (Hajkova et al. 2002, Obata \& Kono 2002). Disruption of this primary imprinting process can lead to altered expression patterns of imprinted genes during embryogenesis.

\section{Re-establishing imprints in the male}

The timing of methylation re-establishment in imprinted genes is less clear for the male germline. However, it appears that paternal imprints are established early in diploid gonocytes (reviewed by Lucifero et al. 2002). Murine $\mathrm{H} 19$ methylation, for example, appears to be initiated in prenatal prospermatogonia and is completed postnatally by the pachytene stage of meiosis (Ueda et al. 2000). Manning et al. (2001) examined the 15q11-13 imprinted 
chromosome region associated with Prader-Willi/Angelmann syndromes and revealed correct paternally established imprints in ejaculated spermatozoa, elongated spermatids and amplified round spermatids, indicating completion of imprinting by the time of haploidisation. Examination of embryos produced by intracytoplasmic sperm injection (ICSI) of round spermatids also revealed normal imprinting of Mash2, Igf2r and mostly of H19, also confirming completion of paternal imprinting prior to meiosis (Shamanski et al. 1999). Zalduendo et al. (2001) examined methylation of the maternally imprinted gene, U2af1-rs1, in three stages of male germ cell line development. Methylation increased as developmental time increased from unmethylated PGCs (or at least in the EG1 cell line derived from $8.5 \mathrm{dpc}$ embryos), through spermatogonial stem cells (6- to 7-day-old mice testes) and mature sperm cells (12- to 16-week-old mice). DNAase 1 sensitivity was also higher in both the PGC-derived EG line and in spermatogonia than in somatic Sertoli cells, suggesting a more open chromatin structure in this imprinted region in the germline.

Another intriguing finding in the re-establishment of imprints has recently been uncovered. It appears that for both Snrpn and H19, acquisition of the paternal imprint occurs at different times during spermatogenesis, depending on whether the spermatogonia originated from a maleor female-derived allele in the diploid PGCs (Davis et al. 2000, Lucifero et al. 2004). Thus, for at least a small subset of genes, these observations challenge the concept of epigenetic reprogramming in the germline resulting in complete equivalence of the germlines prior to meiosis.

The male germline has recently been shown uniquely to express a paralogue of CTCF, known as Brother of the Regulator of Imprinted Sites (BORIS; Loukinov et al. 2002). BORIS is expressed in a mutually exclusive manner with CTCF during male germ cell development, and the erasure of methylation marks during male germline development is associated with dramatic up-regulation of BORIS, as well as down-regulation of CTCF. Remethylation of DNA in round spermatids is associated with the subsequent silencing of BORIS and reactivation of CTCF. Thus BORIS could be associated with demethylases that participate in the erasure of methylation marks, and BORIS-CTCF switching may be intimately linked with initiating (or regional targeting) of de novo DNA methylation in the male germline. Loukinov et al. (2002) also raise the possibility that BORIS may interact with the co-expressed testis-specific histone H3 lysine methylase, Suv39h1, and propose that histone methylation may mark the region-specific DNA for de novo methylation which is then mediated by BORIS or CTCF.

\section{Reprogramming of imprints in the human germline}

No studies are yet available on the full ontogeny of germline epigenetic reprogramming in the human; however there is some information available for late-stage gametes and for preimplantation embryos. SNRPN is methylated in human late-stage germinal vesicle, metaphase I and metaphase II oocytes, and in 4-cell embryos (Geuns et al. 2003). H19 is unmethylated in fetal gonocytes, and methylated in spermatogonia, spermatozoa and preimplantation embryos. IGF2 shows monoallelic expression in the human blastocyst, indicating that differential methylation is at least complete by this stage (Lighten et al. 1997).

Kerjean et al. (2000) also showed that some paternal imprints are established during human spermatogenesis. H19 and PEG1 are unmethylated in fetal spermatogonia, therefore suggesting that all pre-existing methylation imprints are already erased by this stage. PEG1 remains unmethylated at all subsequent post-pubertal stages of spermatogenesis including mature spermatozoa. H19 methylation, typically seen on the paternal allele, first appears in a subset of adult spermatogonia and is then maintained in spermatocytes, spermatids and mature spermatozoa.

Information is beginning to emerge on the DNA methyltransferases that may be associated with genomic imprinting in the human germline. A human homologue of the Dnmt1o gene has been identified in immature oocytes and early preimplantation embryos (Hayward et al. 2003), although the protein has never been examined. However, while Dnmt3l is expressed in mouse oocytes throughout oogenesis, in zygotes and in blastocysts, in humans, DNMT3L appears only to be expressed after fertilisation, and therefore it has been proposed that either DNMT3L may not be involved in establishing imprinting in humans or that there are relative timing differences (Huntriss et al. 2004, Young \& Beaujean 2004).

\section{Errors of epigenetic reprogramming}

Several experimental studies and naturally occurring disease or developmental defects are known to arise from epigenetic defects that may arise in the germline. These defects have been important in contributing to our understanding of the role of and the mechanisms underlying epigenetic phenomena. Here we will consider epigenetic defects that result from genome-wide errors as well as errors in specific loci.

Recently, a human recurrent hydatiform mole phenotype reminiscent of androgenetic extraembryonic tissue, has been described which results from an inherited failure to establish any imprints in the female germline (Judson et al. 2002). The effect of a lack of female imprints has also been demonstrated in nuclear transplantation experiments, using germ cells from various stages of development as diploid donor cells for nuclear transfer into enucleated oocytes (Yamazaki et al. 2003). Embryos thus 'cloned' from $10.5 \mathrm{dpc}$ migrating male germ cells allowed fetal development to mid-gestation, while those from $11.5,12.5,13.5$ and 15.5 dpc embryos or from gonocytes harvested from postnatal ovaries showed a relative developmental delay (Yamazaki et al. 2003). 
Although no studies have examined disrupted imprinting in the early male germline, Marques et al. (2004) have very recently researched the idea that imprinting defects may be associated with disturbed spermatogenesis. MEST (PEG1) and H19 methylation were examined in sperm from normozoospermic and oligozoospermic patients and MEST maternal imprinting was correctly erased in all patients. However, methylation patterns for H19 were abnormal in 23 out of the 96 oligozoospermic patients tested. Most patients had both normally methylated and hypomethylated alleles in the same spermatozoon sample.

Imprinted genes are very important in fetal, placental and behavioural development and monoallelic expression has mostly been identified in prenatal development (Reik et al. 2003). Their misregulation has been implicated in a variety of pathologies including sporadic, inherited and induced growth disorders (Falls et al. 1999, Miozzo \& Simoni 2002, Walter \& Paulsen 2003). Loss of imprinting (resulting in biallelic expression) at growth-related gene loci is well documented to produce growth defects in humans such as Beckwith-Wiedemann syndrome (BWS; Weksberg et al. 2003) or intra-uterine growth restriction (IUGR; Preece 2002), Large Offspring syndrome (LOS) in sheep and cattle (Young et al. 2001) and similar growth effects in genetically manipulated mice (Moore 2001). Other syndromes with more behavioural phenotypes associated with loss of imprinting include Prader-Willi and Angelmann syndromes (Cassidy et al. 2000). In the case of mouse gene targeting experiments, it is clear that the effect arises from an embryonic defect, whilst in the case of LOS and the human syndromes, it is not clear whether germline or embryonic disruptions (or both) have occurred. Increased incidences of the imprinting defects, BWS and Angelman syndrome, have been reported in human-assisted reproduction technologies (ART) in comparison with normally conceived offspring (Gosden et al. 2003, Maher et al. 2003). This raises the possibility that ARTs such as in vitro maturation of oocytes, ovarian hyperstimulation, embryo culture and the use of sub-fertile sperm may introduce imprinting errors into conception and this now requires closer monitoring of infertility treatments (Young \& Fairburn 2000, Young 2003).

A well-understood consequence of aberrant DNA methylation in somatic cells is the formation of tumours, where hypermethylation can silence tumour suppressor genes and hypomethylation can activate oncogenes (Szyf 2003). Teratocarcinomas are tumours containing tissues derived from all three of the germ layers - endoderm, mesoderm and ectoderm. These can arise due to uncontrolled PGC proliferation, perhaps due to ectopic expression of c-Kit or other genes involved in the growth of PGCs, and may be caused by PGCs which have gone astray during the migration from yolk sac to gonadal ridge (Donovan \& de Miguel 2003). If epigenetic reprogramming is misregulated in PGCs, this may provide one possible mechanism for their transformation, although this has not yet been examined. The observation of ectopic PGCs when
E-cadherin-mediated cell adhesion was blocked using antibodies (Bendel-Stenzel et al. 2000) reveals a mechanism which may allow stray cells to move to regions outside the gonad and potentially develop germ cell tumours, perhaps by being exposed to different epigenetic signals. Since many imprinted genes are known tumour suppressors or oncogenes involved in cell proliferation, they often show disrupted imprinting in a variety of adult tumours. Thus, it is of interest that Hernandez et al. (2003) observed opposite effects of the paternal and maternal genomes on proliferation, cell-cycle length, senescence, and tumour formation of androgenetic and parthenogenetic cells in culture.

Epigenetic alterations in DNA methylation in other genomic regions have also been reported, as a consequence of altered nutrition. A maternal hypermethylating diet during mouse pregnancy increased DNA methylation in repetitive sequences, promoting ectopic expression of the agouti gene (Waterland \& Jirtle 2003). Since the hypermethylating diet in this study was applied during oogenesis, pregnancy and weaning, it is not possible yet to discern whether nutrients can specifically affect methylation of the germline, but the human health implications certainly make it a possibility that merits testing (Young 2001, Young et al. 2004).

\section{Epigenetic reprogramming of gametes after fertilisation}

The mouse genome undergoes two major phases of epigenetic reprogramming, once in the primordial germ cells and once in the preimplantation embryo. The mouse genome undergoes two major phases of epigenetic reprogramming once in the primordial germ cells and once in the preimplantation embryo (Fig. 3). Both involve genome-wide erasure of DNA methylation and then a period of locus-specific de novo methylation, but only in the PGCs are imprints erased and re-established (Santos \& Dean 2004). After fertilisation in mice, during pre-implantation and early post-implantation stages, demethylation takes place; however, this does not affect the parental genomes to an equal extent, such that even in the embryo the two germlines exhibit differences in epigenetic reprogramming. Whilst the paternal pronuclear genome is rapidly demethylated in the newly fertilised egg, the maternal genome is gradually demethylated during the first cell cleavages (Mayer et al. 2000). Equivalent levels of hypomethylation of both parental genomes are reached by the 16-cell stage then the combined embryonic genomes are de novo methylated in the inner cell mass of the murine blastocyst (Santos et al. 2002).

Whilst the global demethylation of the paternal genome observed in the mouse embryo has also been reported in the rat, pig, cow (Dean et al. 2001) and human (Beaujean et al. 2004a) zygote, this does not occur in either the sheep or rabbit embryo (Beaujean et al. 2004a, Shi et al. 2004) and thus is not representative of all mammals. 


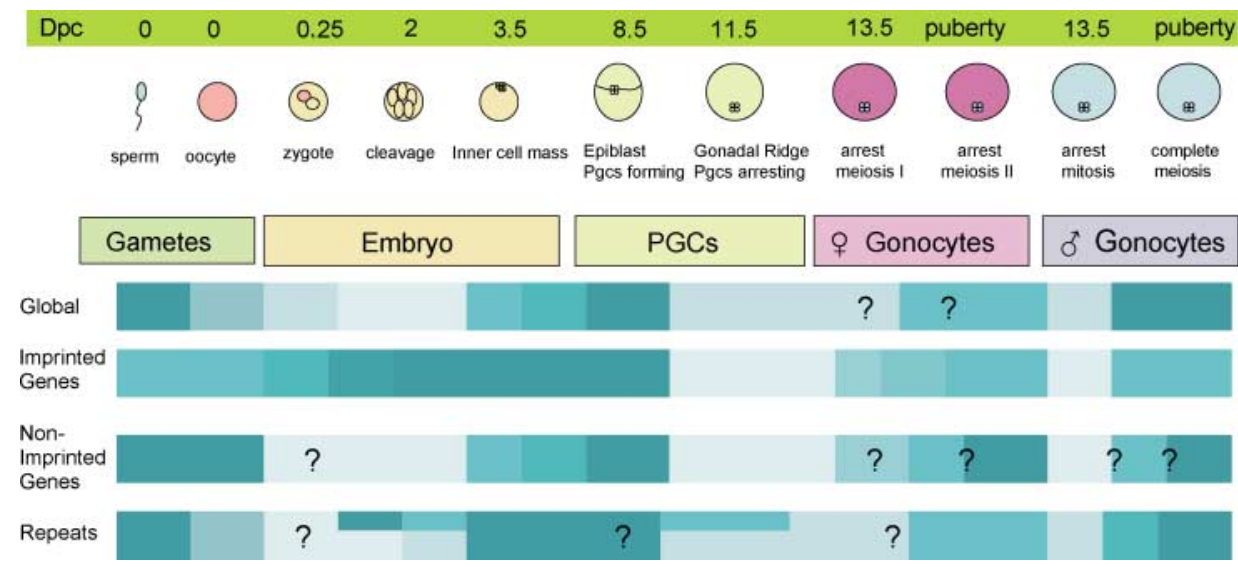

Figure 3 Schematic representation of the methylation dynamics of different components of the mouse genome during germline development. Darker bands represent higher levels of methylation and question marks indicate either that differences have been identified between sequences in the category presented or that the information is based on limited information. Global changes in genomic methylation have been examined using an antibody against 5-methylcytosine, which reveals major changes in methylation-dense regions such as centromeric heterochromatin, but which has insufficient sensitivity to detect changes in low copy number loci. Within single loci, the imprinted genes have been the most extensively studied, in addition to a few non-imprinted genes. In addition, methylation of both centromeric Satellite repeat sequences and of some dispersed repeat sequences (both important for genomic stability) undergo germline reprogramming. See text for discussion of species differences.

Insights into these species differences have recently been provided by interspecies ICSI experiments, which have shown greater demethylating capacity of mouse ooplasm compared with that of the sheep, in addition to greater protection of sheep sperm from demethylation (Beaujean et al. 2004b). Why the zygote of some species requires rapid demethylation of the sperm pronucleus in the zygote is still an open question, but it may relate to the timing of embryonic genome activation, the composition of the genome, differences in reproductive strategies or it may be related to genomic imprinting (see Young \& Beaujean 2004 for discussion). A more limited global demethylation event than in the mouse is also observed in the sheep, cow and rabbit genomes between the zygote and the 8-cell stages (Bourc'his et al. 2001b, Beaujean et al. 2004a, Shi et al. 2004), but these do not appear to be globally remethylated, at least prior to the blastocyst stage. In the ruminants, this cleavage stage demethylation does not appear limited to a single parental genome.

At least for the mouse, information on other germlinespecific chromatin modifications is emerging. Concurrent with higher transcriptional activity in the larger male murine pronucleus, hyperacetylation of paternal pronuclear DNA has been observed relative to the female pronucleus and sperm/metaphase II oocytes (Adenot et al. 1997). Arney et al. (2002) have demonstrated that metaphase II oocytes chromosomes and female pronuclei have high levels of methylation on $\mathrm{H} 3-\mathrm{K} 9$. The paternal genome shows no methylated H3-K9 immunostaining shortly after fertilisation and it is suggsted that this differential chromatin modification recruits maternally stored heterochromatin protein, $H p 1 \beta$, exclusively to the maternal genome. This early recruitment of heterochromatin-associated proteins provides a plausible mechanism for masking maternal chromatin from demethylation at the pronuclear stage, a question that will perhaps be unravelled by interspecies studies.

\section{New experimental models for germline epigenetic investigation}

The difficulty in obtaining and analysing the small number of PGCs and their derivatives even in the mouse embryo has limited the studies on epigenetic reprogramming that have been carried out to date, despite this appearing to be a fundamental developmental event with severe consequences if misregulation occurs. Several experimental models have recently been developed which may lead to novel sources of material for study in the future, particularly in the human.

\section{EG cells}

In vitro transformation of mouse EG cell lines from PGCs (Matsui et al. 1992, Resnick et al. 1992) results in similar cell appearance, proliferation characteristics and marker expression (McLaren \& Durcova-Hills 2001) but, unlike PGCs, EG cells are pluripotent (Matsui et al. 1992) and can form germline chimeras (Labosky et al. 1994a, Stewart et al. 1994). Mouse EG cells derived from PGCs isolated at different stages during development have shown that these cells largely undergo epigenetic modifications characteristic of the germline in vivo (Hajkova et al. 2002).

Imprint analysis on EG cells derived from $8.0-9.5 \mathrm{dpc}$ PGCs revealed some degree of erasure (Labosky et al. 1994b, Stewart et al. 1994, Durcova-Hills et al. 2001), consistent with the nuclear transplantation studies of Yamazaki et al. 2003. Extensive hypomethylation of the 
Igf2r, Peg3, Peg1/Mes, p57Kip2 and Nnat imprinted genes has been observed in female and male EG cells derived from 11.5-12.5 dpc PGCs (Labosky et al. 1994b, Tada et al. 1998). Chimeras made with post-migratory EG cells show fetal overgrowth and skeletal abnormalities, consistent with the reduced methylation of paternally imprinted genes. Hypomethylation was more evident in EG cells derived from male embryos (Tada et al. 1998), a feature dependent on the cellular sex chromosome constitution rather than on the sex of the genital ridge (Durcova-Hills et al. 2004). Of interest is that $12.5 \mathrm{dpc}$ mouse EG cells can induce reprogramming of a somatic nucleus in cell hybrids by changing the methylation status of imprinted and non-imprinted genes (Tada et al. 1997). Many attempts to derive EG cell lines from later developmental stages have not been successful thus far.

Whether EG cells continue to follow a developmental programme that is already established for the PGCs in the embryo or whether there is a progressive loss of methylation during culture (Labosky et al. 1994a, b, McLaren 2003, Durcova-Hills et al. 2004) is open to question. The latter hypothesis is supported by the evidence that an altered methylation profile has been detected in mouse embryonic stem (ES) cells in culture (Dean et al. 1998).

More recently, EG cell lines have been derived by using human PGCs from gonadal ridges and mesenteries from 5-11 weeks post-fertilisation (Shamblott et al. 1998, 2001). The human EG cells resemble mouse EG cells in terms of phenotype, marker expression and pluripotent characteristics (Shamblott et al. 1998, 2001); however the maintenance of these lines in culture has only been achieved up to 20 passages (Shamblott et al. 1998, Turnpenny et al. 2003), making their characterisation very difficult. The methylation profile of imprinted genes has thus far only been analysed in human EG cell-differentiated derivatives, because of the impossibility of maintaining the undifferentiated EG cells in culture (Onyango et al. 2002). In comparison with derivatives of mouse EG cells derived at $8.5 \mathrm{dpc}$, human EG cell derivatives from fetuses of 5-11 weeks post-fertilisation maintained the parental imprinting status, and the authors suggest that the time of imprint erasure differs in the two species. Since the human EG cell lines were reported to be derived from both the mesentery (en route to the gonadal ridge when mouse PGCs have only undergone limited demethylation) and from the gonadal ridge (where mouse PGCs undergo dramatic erasure after 1-2 days), further examination of individual lines and information on imprinting status before differentiation or the equivalent differentiated cell types in vivo is required to substantiate these conclusions.

\section{Germ cells from ES cells}

An exciting development in terms of potentially providing germ cell material for epigenetic study follows the observations that mouse and human ES cells can differentiate to germ cells and their male and female derivatives in vitro. Mouse ES cells can spontaneously differentiate to different stages of germ cell development expressing markers of the pre-migratory (oct4, cKit) and post-migratory (vasa; Hubner et al. 2003, Toyooka et al. 2003) phases. ES-derived germ cells were able to develop ovarian follicle homologues with oocytes that can enter meiosis and form parthenogenetic blastocyst-like structures (Hubner et al. 2003). However, the lack of expression of the zona pellucida ZP1 questions the ability of these oocytes to undergo normal fertilisation. Recent advances in promoting gametogenesis in vitro may combine with ES technology to improve the efficiency of mimicking full germline differentiation in vitro. Notably, mouse pre-meiotic female germ cells isolated from the $12.5 \mathrm{dpc}$ fetus have recently been stimulated to undergo substantial oogenesis in vitro (Obata et al. 2002). The isolated oocytes at different stages of development showed the expected in vivo methylation pattern of the Igf2r imprinted gene, suggesting that epigenetic reprogramming is being accomplished in vitro. However, another study reported inappropriate methylation of the Igf2r and Peg1 loci during in vitro oocyte growth in pre-antral follicle culture (Kerjean et al. 2003), thus factors such as optimisation of culture conditions will prove an important consideration in experimental design.

It has also been demonstrated that mouse ES cells can form post-migrating-type male germ cells in differentiating embryoid bodies (EBs) (Toyooka et al. 2003). This differentiation can be stimulated by BMP4-producing cells, mimicking the pathway for germ cell specification in vivo. These can undergo meiosis and spermatogenesis and differentiate into sperm when transplanted into the testis capsule. Geijsen et al. (2004) stimulated mouse EBderived PGCs with retinoic acid to differentiate haploid round spermatids that could initiate fertilisation of oocytes after ICSI, suggesting that ES cells can give rise to germ cells by several routes in vitro. Interestingly, it has been shown that it is possible to derive EG cell lines from mouse ES-derived germ cells (Geijsen et al. 2004). These EG cells show a somatic-like imprinting status of the $\lg 2 \mathrm{r}$ and $\mathrm{H} 19$ genes when derived from day $4 \mathrm{EBs}$, but the imprinting methylation profile was erased at day 7 of EB differentiation, demonstrating that the PGCs derived from EBs may be able to mimic the epigenetic reprogramming features of PGCs developing in vivo.

To date, just one attempt to derive germ cells from human ES cells has been reported (Clark et al. 2004). Human ES cells were differentiated spontaneously through EB formation and were shown to give rise to cell-expressing germ cell markers. In contrast to the mouse system, human ES-differentiated germ cells expressed both female (GDF9, oocyte- specific) and male (TEKT1, spermatidspecific) germline markers. However, a low degree of meiotic marker expression was detected during human ES differentiation, suggesting that the spontaneous production of gametes in vitro is a more inefficient process in human. Cells with PGC or gametic phenotypes remain to be 
isolated from human ES cells, but the likely possibility that this will be achieved will give rise to many exciting new experimental possibilities.

\section{Novel model organisms}

While lower model organisms have previously provided powerful tools for examining developmental mechanisms conserved in mammals, germline specification and epigenesis studies have been hampered by the use of germplasm, rather than epigenesis, to form PGCs in species such as Xenopus, zebrafish and Drosophila. Intriguingly, Johnson et al. $(2003 a, b)$ have recently demonstrated that the axolotl makes PGCs in a mechanism highly conserved with mammals, involving BMP4 induction, and the switching on of oct4, vasa and dazl. Since neither zebrafish or Xenopus undergo the genome-wide demethylation reprogramming event that mammals undergo post-fertilisation (MacLeod et al. 1999, Stancheva \& Meehan 2000) it will be of interest to compare the scenario in axolotl, both post-fertilisation and during PGC formation.

\section{The future}

The above examples of continuous development of methods for the formation and survival of primordial germ cells and gametes in culture constantly provides new opportunities to study and modify the key developmental process of epigenetic reprogramming. It is very likely that procedures in both ART and somatic cell nuclear transfer could be improved and become more efficient and safer if a better understanding of epigenetic reprogramming in the germline and preimplantation embryo were available.

\section{Acknowledgements}

We are grateful to Angela Prescott and Susan Kirk for secretarial help and to Andrew Johnson for interesting discussions. The LEY lab group acknowledges funding in this area from BBSRC, NIH, University of Nottingham and British Council. The authors declare that there is no conflict of interest that would prejudice the impartiality of this scientific work.

\section{References}

Adenot PG, Mercier Y, Renard JP \& Thompson EM 1997 Differential $\mathrm{H} 4$ acetylation of paternal and maternal chromatin precedes DNA replication and differential transcriptional activity in pronuclei of 1-cell mouse embryos. Development 124 4615-4625.

Anderson R, Fässler R, Georges-Labouesse E, Hynes RO, Bader BL, Kreidberg JA, Schaible K, Heasman J \& Wylie C 1999 Mouse primordial germ cells lacking $\beta 1$ integrins enter the germline but fail to migrate normally to the gonads. Development $\mathbf{1 2 6}$ 1655-1664.

Arney KL, Bao S, Bannister AJ, Kouzarides T \& Surani MA 2002 Histone methylation defines epigenetic asymmetry in the mouse zygote. International Journal of Developmental Biology $\mathbf{4 6}$ $317-320$.

Beaujean N, Hartshorne G, Cavilla J, Taylor J, Gardner J, Wilmut I, Meehan R \& Young L 2004a Non-conservation of mammalian pre- implantation methylation dynamics. Current Biology $\mathbf{1 4}$ R266-R267.

Beaujean N, Taylor JE, McGarry M, Gardner JO, Wilmut I, Loi P, Ptak G, Galli C, Lazzari G, Bird A, Young LE \& Meehan RR 2004b The effect of interspecific oocytes on demethylation of sperm DNA. PNAS 101 7636-7640.

Bendel-Stenzel MR, Gomperts M, Anderson R, Heasman J \& Wylie C 2000 The role of cadherins during primordial germ cell migration and early gonad formation in the mouse. Mechanisms of Development 91 143-152.

Bird A 2002 DNA methylation patterns and epigenetic memory. Genes and Development 16 6-21.

Bourc'his D, Le Bourhis D, Patin D, Niveleau A, Comizzoli P, Renard JP \& Viegas-Pequignot E 2001a Delayed and incomplete reprogramming of chromosome methylation patterns in bovine cloned embryos. Current Biology 11 1542-1546.

Bourc'his D, Xu GL, Lin CS, Bollman B \& Bestor TH $2001 b$ Dnmt3L and the establishment of maternal genomic imprints. Science 294 $2536-2539$.

Burgess-Beusse B, Farrell C, Gaszner M, Litt M, Mutskov V, RecillasTarga F, Simpson M, West A \& Felsenfeld G 2002 The insulation of genes from external enhancers and silencing chromatin. PNAS 99 $16433-16437$.

Cassidy SB, Dykens E \& Williams CA 2000 Prader-Willi and Angelman syndromes: sister imprinted disorders. American Journal of Medical Genetics 97 136-146.

Chedin F, Lieber MR \& Hsieh CL 2002 The DNA methyltransferaselike protein DNMT3L stimulates de novo methylation by Dnmt3a. PNAS 99 16916-16921.

Clark AT, Bodnar MS, Fox M, Rodriquez RT, Abeyta MJ, Firpo MT \& Pera RA 2004 Spontaneous differentiation of germ cells from human embryonic stem cells in vitro. Human Molecular Genetics $13727-739$

Coffigny H, Bourgeois C, Ricoul M, Bernardino J, Vilain A, Niveleau A, Malfoy B \& Dutrillaux B 1999 Rations of DNA methylation patterns in germ cells and Sertoli cells from developing mouse testis. Cytogenetics and Cell Genetics 87 175-181.

Constancia M, Pickard B, Kelsey G \& Reik W 1998 Imprinting mechanisms. Genome Research 8 881-900.

Cowell IG, Aucott R, Mahadevaiah SK, Burgoyne PS, Huskisson N, Bongiorni S, Prantera G, Fanti L, Pimpinelli S, Wu R, Gilbert DM, Shi W, Fundele R, Morrison H, Jeppesen P \& Singh PB 2002 Heterochromatin, HP1 and methylation at lysine 9 of histone $\mathrm{H} 3$ in animals. Chromosoma $11122-36$.

Davis TL, Yang GJ, McCarrey JR \& Bartolomei MS 2000 The H19 methylation imprint is erased and re-established differentially on the parental alleles during male germ cell development. Human Molecular Genetics 9 2885-2894.

Dean W, Bowden L, Aitchison A, Klose J, Moore T, Meneses JJ, Reik W \& Feil R 1998 Altered imprinted gene methylation and expression in completely ES cell-derived mouse fetuses: association with aberrant phenotypes. Development 125 2273-2282.

Dean W, Santos F, Stojkovic M, Zakhartchenko V, Walter J, Wolf E \& Reik W 2001 Conservation of methylation reprogramming in mammalian development: aberrant reprogramming in cloned embryos. PNAS 98 13734-13738.

Doherty AS, Bartolomei MS \& Schultz RM 2002 Regulation of stagespecific nuclear translocation of Dnmt1o during preimplantation mouse development. Developmental Biology 242 255-266.

Donovan PJ \& de Miguel MP 2003 Turning germ cells into stem cells. Current Opinion in Genetics and Development 13 463-471.

Donovan PJ, Stott D, Cairns LA, Heasman J \& Wylie CC 1986 Migratory and postmigratory mouse primordial germ cells behave differently in culture. Cell 44 831-838.

Durcova-Hills G, Ainscough J \& McLaren A 2001 Pluripotential stem cells derived from migrating primordial germ cells. Differentiation $68220-226$ 
Durcova-Hills G, Burgoyne P \& McLaren A 2004 Analysis of sex differences in EGC imprinting. Developmental Biology 268 105-110.

Falls JG, Pulford DJ, Wylie AA \& Jirtle RL 1999 Genomic imprinting: implications for human disease (Review). American Journal of Pathology 154 635-647.

Fedoriw AM, Stein P, Svoboda P, Schultz RM \& Bartolomei MS 2004 Transgenic RNAi reveals essential function for CTCF in $\mathrm{H} 19$ gene imprinting. Science $303238-240$.

Feil R \& Khosla S 1999 Genomic imprinting in mammals: an interplay between chromatin and DNA methylation? Trends in Genetics. 15 431-435.

Feil R, Khosla S, Cappai P \& Loi P 1998 Genomic imprinting in ruminants: allele-specific gene expression in parthenogenetic sheep. Mammalian Genome 9 831-834.

Felsenfeld G \& Groudine M 2003 Controlling the double helix. Nature 421 448-453.

Geijsen N, Horoschak M, Kim K, Gribnau J, Eggan K \& Daley GQ 2004 Derivation of embryonic germ cells and male gametes from embryonic stem cells. Nature 427 148-154.

Geuns E, De Rycke M, Van Steirteghem A \& Liebaers I 2003 Methylation imprints of the imprint control region of the SNRPNgene in human gametes and preimplantation embryos. Human Molecular Genetics 12 2873-2879.

Gidekel S \& Bergman Y 2002 A unique developmental pattern of Oct-3/4 DNA methylation is controlled by a cis-demodification element. Journal of Biological Chemistry 277 34521-34530.

Ginsburg M, Snow MH \& McLaren A 1990 Primordial germ cells in the mouse embryo during gastrulation. Development $\mathbf{1 1 0}$ 521-528.

Gosden R, Trasler J, Lucifero D \& Faddy M 2003 Rare congenital disorders, imprinted genes, and assisted reproductive technology. Lancet 361 1975-1977.

Goto T, Adjaye J, Rodeck CH \& Monk M 1999 Identification of genes expressed in human primordial germ cells at the time of entry of the female germ line into meiosis. Molecular Human Reproduction. 5 851-860.

Goto T, Jones GM, Lolatgis N, Pera MF, Trounson AO \& Monk M 2002 Identification and characterisation of known and novel transcripts expressed during the final stages of human oocyte maturation. Molecular Reproduction and Development 62 $13-28$.

Hagemann LJ, Peterson AJ, Weilert LL, Lee RS \& Tervit HR 1998 In vitro and early in vivo development of sheep gynogenones and putative androgenones. Molecular Reproduction and Development 50 154-162.

Hajkova P, Erhardt S, Lane N, Haaf T, El-Maarri O, Reik W, Walter J \& Surani MA 2002 Epigenetic reprogramming in mouse primordial germ cells. Mechanisms of Development 117 15-23.

Hata K, Okano M, Lei H \& Li E 2002 Dnmt3L cooperates with the Dnmt3 family of de novo DNA methyltransferases to establish maternal imprints in mice. Development 129 1983-1993.

Hattori N, Nishino K, Ko YG, Hattori N, Ohgane J, Tanaka S \& Shiota K 2004 Epigenetic control of mouse Oct-4 gene expression in embryonic stem cells and trophoblast stem cells. Journal of Biological Chemistry 279 17063-17069.

Hayward BE, De Vos M, Judson H, Hodge D, Huntriss J, Picton HM, Sheridan E \& Bonthron DT 2003 Lack of involvement of known DNA methyltransferases in familial hydatidiform mole implies the involvement of other factors in establishment of imprinting in the human female germline. BioMed Central Genetics 4 2-9.

Hernandez L, Kozlov S, Piras G \& Stewart CL 2003 Paternal and maternal genomes confer opposite effects on proliferation, cellcycle length, senescence and tumor formation. PNAS $\mathbf{1 0 0}$ 13344-13349.

Howlett SK \& Reik W 1991 Methylation levels of maternal and paternal genomes during preimplantation development. Development. 113 119-127.
Hubner K, Fuhrmann G, Christenson LK, Kehler J, Reinbold R, De la Fuente R, Wood J, Strauss JF 3rd, Boiani M \& Scholer HR 2003 Derivation of oocytes from mouse embryonic stem cells. Science $3001251-1256$.

Huntriss J, Hinkins M, Oliver B, Harris SE, Beazley JC, Rutherford AJ, Gosden RG, Lanzendorf SE \& Picton HM 2004 Expression of mRNAs for DNA methyltransferases and methyl-CpG-binding proteins in the human female germ line, preimplantation embryos, and embryonic stem cells. Molecular Reproduction and Development $67323-336$.

Jablonka E \& Lamb RM 1998 Epigenetic inheritance in evolution. Journal of Evolutionary Biology 11 159-183.

Jaenisch R 1997 DNA methylation and imprinting: why bother? Trends in Genetics 13 323-329.

Jaenisch R \& Bird A 2003 Epigenetic regulation of gene expression: how the genome integrates intrinsic and environmental signals. Nature Genetics 33 (Suppl) 245-254.

Johnson AD, Crother B, White ME, Patient R, Bachvarova RF, Drum M \& Masi T 2003a Regulative germ cell specification in axolotl embryos: a primitive trait conserved in the mammalian lineage. Philosophical Transactions of the Royal Society of London 358 1371-1379.

Johnson AD, Drum M, Bachvarova RF, Masi T, White ME \& Crother BI $2003 b$ Evolution of predetermined germ cells in vertebrate embryos: implications for macroevolution. Evolution and Development 5 414-431.

Jones PA \& Takai D 2001 The role of DNA methylation in mammalian epigenetics. Science 293 1068-1070.

Judson H, Hayward BE, Sheridan E \& Bonthron DT 2002 A global disorder of imprinting in the human female germ line. Nature $\mathbf{4 1 6}$ 539-542.

Kafri T, Ariel M, Brandeis M, Shemer R, Urven L, McCarrey J, Cedar H \& Razin A 1992 Developmental pattern of gene-specific DNA methylation in the mouse embryo and germ line. Genes and Development 6 705-714.

Kerjean A, Dupont JM, Vasseur C, Le Tessier D, Cuisset L, Paldi A, Jouannet P \& Jeanpierre M 2000 Establishment of the paternal methylation imprint of the human $\mathrm{H} 19$ and MEST/PEG1 genes during spermatogenesis. Human Molecular Genetics 9 $2183-2187$.

Kerjean A, Couvert P, Heams T, Chalas C, Poirier K, Chelly J, Jouannet P, Paldi A \& Poirot C 2003 In vitro follicular growth affects oocyte imprinting establishment in mice. European Journal of Human Genetics 11 493-496.

Knower KC, Kelly S \& Harley VR 2003 Turning on the male - SRY, SOX9 and sex determination in mammals. Cytogenetic and Genome Research 101 185-198.

Kono T, Obata Y, Yoshimzu T, Nakahara T \& Carroll J 1996 Epigenetic modifications during oocyte growth correlates with extended parthenogenetic development in the mouse. Nature Genetics 13 91-94.

Kono T, Obata Y, Wu Q, Niwa K, Ono Y, Yamamoto Y, Park ES, Seo JS \& Ogawa H 2004 Birth of parthenogenetic mice that can develop to adulthood. Nature 428 860-864.

Labosky PA, Barlow DP \& Hogan BL 1994a Embryonic germ cell lines and their derivation from mouse primordial germ cells. Ciba Foundation Symposium 182 157-168.

Labosky PA, Barlow DP \& Hogan BL 1994b Mouse embryonic germ (EG) cell lines: transmission through the germline and differences in the methylation imprint of insulin-like growth factor 2 receptor (Igf2r) gene compared with embryonic stem (ES) cell lines. Development 120 3197-3204.

Lander ES, Linton LM, Birren B, Nusbaum C, Zody MC, Baldwin J, Devon K, Dewar K, Doyle M, FitzHugh W et al. 2001 Initial sequencing and analysis of the human genome. Nature 409 860-921.

Lane N, Dean W, Erhardt S, Hajkova P, Surani A, Walter J \& Reik W 2003 Resistance of IAPs to methylation reprogramming may 
provide a mechanism for epigenetic inheritance in the mouse. Genesis 35 88-93.

Lange UC, Saitou M, Western PS, Barton SC \& Surani MA 2003 The Fragilis interferon-inducible gene family of transmembrane proteins is associated with germ cell specification in mice. $B M C$ Developmental Biology 3 1-11.

Larsen WJ 2001 In Human Embryology, 3rd ed. Philadelphia, USA: Churchill Livingstone.

Lawson KA \& Hage WJ 1994 Clonal analysis of the origin of primordial germ cells in the mouse. In CIBA Foundation Symposium 182: Germline Development, pp 68-91. Eds J Marsh and J Goode. Chichester, UK: John Wiley and Sons.

Li E 2002 Chromatin modification and epigenetic reprogramming in mammalian development. Nature Review. Genetics 3 662-673.

Lighten AD, Hardy K, Winston RM \& Moore GE 1997 IGF2 is parentally imprinted in human preimplantation embryos. Nature Genetics 15 122-123.

Loriot A, Boon T \& De Smet C 2003 Five new human cancer-germline genes identified among 12 genes expressed in spermatogonia. International Journal of Cancer 105 371-376.

Loukinov DI, Pugacheva E, Vatolin S, Pack SD, Moon H, Chernukhin I, Mannan P, Larsson E, Kanduri C, Vostrov AA, Cui H, Niemitz EL, Rasko JE, Docquier FM, Kistler M, Breen JJ, Zhuang Z, Quitschke WW, Renkawitz R, Klenova EM, Feinberg AP, Ohlsson R, Morse HC 3rd \& Lobanenkov VV 2002 BORIS, a novel male germ-line-specific protein associated with epigenetic reprogramming events, shares the same 11-zinc-finger domain with CTCF, the insulator protein involved in reading imprinting marks in the soma. PNAS 99 6806-6811.

Lucifero D, Mann MR, Bartolomei MS \& Trasler JM 2004 Genespecific timing and epigenetic memory in oocyte imprinting. Human Molecular Genetics 13 839-849.

Lucifero D, Mertineit C, Clarke HJ, Bestor TH \& Trasler JM 2002 Methylation dynamics of imprinted genes in mouse germ cells. Genomics 79 530-538.

Lyle R 1997 Gametic imprinting in development and disease. Journal of Endocrinology 155 1-12.

MacLeod D, Clark VH \& Bird A 1999 Absence of genome-wide changes in DNA methylation during development of the Zebrafish. Nature Genetics 23 139-140.

McLaren A 2003 Primordial germ cells in the mouse. Developmental Biology 262 1-15.

McLaren A \& Durcova-Hills G 2001 Germ cells and pluripotent stem cells in the mouse. Reproduction, Fertility and Development $\mathbf{1 3}$ 661-664.

Maher ER, Afnan M \& Barratt CL 2003 Epigenetic risks related to assisted reproductive technologies: epigenetics, imprinting, ART and icebergs? Human Reproduction 18 2508-2511.

Manning M, Lissens W, Weidner W \& Liebaers I 2001 DNA methylation analysis in immature testicular sperm cells at different developmental stages. Urologia Internationalis 67 151-155.

Marques CJ, Carvalho F, Sousa M \& Barros A 2004 Genomic imprinting in disruptive spermatogenesis. Lancet 363 1700-1702.

Matsui Y, Zsebo K \& Hogan BL 1992 Derivation of pluripotential embryonic stem cells from murine primordial germ cells in culture. Cell 70 841-847.

Mayer W, Niveleau A, Walter J, Fundele R \& Haaf T 2000 Demethylation of the zygotic paternal genome. Nature 403 501-502.

Meehan RR 2003 DNA methylation in animal development. Seminars in Cell and Developmental Biology 14 53-65.

Meehan RR, Pennings S \& Stancheva I 2001 Lashings of DNA methylation, forkfuls of chromatin remodeling. Genes and Development 15 3231-3236.

Mertineit C, Yoder JA, Taketo T, Laird DW, Trasler JM \& Bestor TH 1998 Sex-specific exons control DNA methyltransferase in mammalian germ cells. Development 125 889-897.

Miozzo M \& Simoni G 2002 The role of imprinted genes in fetal growth. Biology of the Neonate 81 217-228.
Monk M, Boubelik M \& Lehnert S 1987 Temporal and regional changes in DNA methylation in the embryonic, extraembryonic and germ cell lineages during mouse embryo development. Development. $99371-382$.

Moore T 2001 Genetic conflict, genomic imprinting and establishment of the epigenotype in relation to growth. Reproduction 122 185-193.

Moore T \& Ball M 2004 Kaguya, the first parthenogenetic mammal engineering triumph or lottery winner? Reproduction 128 1-3.

Nagy A, Gertsenstein M, Vintersten K \& Behringer R 2003 In Manipulating the Mouse Embryo: A Laboratory Manual, 3rd ed. New York, USA: Cold Spring Harbour Laboratory Press.

Nishino K, Hattori N, Tanaka S \& Shiota K 2004 DNA methylation-mediated control of Sry gene expression in mouse gonadal development. Journal of Biological Chemistry 279 22306-22313.

Noce T, Okamoto-Ito S \& Tsunekawa N 2001 Vasa homolog genes in mammalian germ cell development. Cell Structure and Function $26131-136$.

Obata Y \& Kono T 2002 Maternal primary imprinting is established at a specific time for each gene throughout oocyte growth. Journal of Biological Chemistry 15277 5285-5289.

Obata Y, Kaneko-Ishino T, Koide T, Takai Y, Ueda T, Domeki I, Shiroishi T, Ishino F \& Kono T 1998 Disruption of primary imprinting during oocyte growth leads to the modified expression of imprinted genes during embryogenesis. Development 125 1553-1560.

Obata Y, Kono T \& Hatada I 2002 Gene silencing: maturation of mouse fetal germ cells in vitro. Nature 418497.

Olek A \& Walter J 1997 The preimplantation ontogeny of H19 methylation imprint. Nature Genetics 17 275-276.

Onyango P, Jiang S, Uejima H, Shamblott MJ, Gearhart JD, Cui H \& Feinberg AP 2002 Monoallelic expression and methylation of imprinted genes in human and mouse embryonic germ cell lineages. PNAS 99 10599-10604.

Oswold J, Engemann S, Lane N, Mayer W, Olek A, Fundele R, Dean W, Reik W \& Walter J 2000 Active demethylation of the paternal genome in mouse zygote. Current Biology 10 475-478.

Paulsen M \& Ferguson-Smith AC 2001 DNA methylation in genomic imprinting, development, and disease. Journal of Pathology 195 97-110.

Payer B, Saitou M, Barton SC, Thresher R, Dixon JPC, Zahn D, Colledge WH, Carlton MBL, Nakano T \& Surani MA 2003 Stella is a maternal effect gene required for normal early development in mice. Current Biology 13 2110-2117.

Picton H, Briggs D \& Gosden R 1998 The molecular basis of oocyte growth and development. Molecular and Cellular Endocrinology $14527-37$.

Ponzetto-Zimmerman C \& Wolgemuth DJ 1984 Methylation of satellite sequences in mouse spermatogenic and somatic DNAs. Nucleic Acids Research 12 2807-2822.

Pradhan S \& Esteve EO 2003 Mammalian DNA (cytosine-5) methyltransferases and their expression. Clinical Immunology 109 6-16.

Preece MA 2002 The genetics of the Silver-Russell syndrome. Reviews in Endocrine and Metabolic Disorders 3 369-379.

Rakyan VK, Preis J, Morgan HD \& Whitelaw E 2001 The marks, mechanisms and memory of epigenetic states in mammals. Biochemical Journal 356 1-10.

Rakyan VK, Chong S, Champ ME, Cuthbert PC, Morgan HD, Luu KV \& Whitelaw E 2003 Transgenerational inheritance of epigenetic states at the murine Axin(Fu) allele occurs after maternal and paternal transmission. PNAS $1002538-2543$.

Readhead C \& Muller-Tidow C 2002 Genes associated with the development of the male germ line. Reproductive Biomedicine Online 4 52-57.

Reik W \& Dean W 2001 DNA methylation and mammalian epigenetics. Electrophoresis 22 2838-2843.

Reik W, Dean W \& Walter J 2001 Epigenetic reprogramming in mammalian development. Science 293 1089-1093. 
Reik W \& Walter J 2001 Genomic imprinting: parental influence on the genome. Nature Reviews. Genetics 2 21-32.

Reik W, Constancia M, Fowden A, Anderson N, Dean W, FergusonSmith A, Tycko B \& Sibley C 2003 Regulation of supply and demand for maternal nutrients in mammals by imprinted genes. Journal of Physiology 547 35-44.

Resnick JL, Bixler LS, Cheng L \& Donovan PJ 1992 Long-term proliferation of mouse primordial germ cells in culture. Nature 359 $550-551$.

Sadler TW 2004 In Langman's Medical Embryology, Baltimore, USA: Lippincott, Williams and Wilkins.

Saitou M, Barton SC \& Surani MA 2002 A molecular programme for the specification of germ cell fate in mice. Nature 418 293-300.

Sanford J, Forrester L, Chapman V, Chandley A \& Hastie N 1984 Methylation patterns of repetitive DNA sequences in germ cells of Mus musculus. Nucleic Acids Research 12 2823-2836.

Sanford JP, Clark HJ, Chapman VM \& Rossant J 1987 Differences in DNA methylation during oogenesis and spermatogenesis and their persistence during early embryogenesis in the mouse. Genes and Development 1 1039-1046.

Santos F \& Dean W 2004 Epigenetic reprogramming during early development in mammals. Reproduction 127 643-651.

Santos F, Hendrich B, Reik W \& Dean W 2002 Dynamic reprogramming of DNA methylation in the early mouse embryo. Developmental Biology 241 172-182.

Sato S, Yoshimizu T, Sato E \& Matsui Y 2003 Erasure of methylation imprinting of Igf $2 \mathrm{r}$ during mouse primordial germ-cell development. Molecular Reproduction and Development 65 41-50.

Saunders PTK, Turner JMA, Ruggiu M, Taggart M, Burgoyne PS, Elliot D \& Cooke HJ 2003 Absence of mDazl produces a final block on germ cell development at meiosis. Reproduction 126 589-597.

Shamanski FL, Kimura Y, Lavoir MC, Pedersen RA \& Yanagimachi R 1999 Status of genomic imprinting in mouse spermatids. Human Reproduction 14 1050-1056.

Shamblott MJ, Axelman J, Wang S, Bugg EM, Littlefield JW, Donovan PJ, Blumenthal PD, Huggins GR \& Gearhart JD 1998 Derivation of pluripotent stem cells from cultured human primordial germ cells. PNAS 95 13726-13731.

Shamblott MJ, Axelman J, Littlefield JW, Blumenthal PD, Huggins GR, Cui Y, Cheng L \& Gearhart JD 2001 Human embryonic germ cell derivatives express a broad range of developmentally distinct markers and proliferate extensively in vitro. PNAS 98 113-118.

Shi W, Dirim F, Wolf E, Zakhartchenko V \& Haaf T 2004 Methylation reprogramming and chromosomal aneuploidy in in vivo fertilized and cloned rabbit preimplantation embryos. Biology of Reproduction 71 340-347.

Shiota K, Kogo Y, Ohgane J, Imamura T, Urano A, Nishino K, Tanaka S \& Hattori N 2002 Epigenetic marks by DNA methylation specific to stem, germ and somatic cells in mice. Genes to Cells $\mathbf{9}$ 961-969.

Stancheva I \& Meehan RR 2000 Transient depletion of xDnmt1 leads to premature gene activation in Xenopus embryo's. Genes and Development 14 313-327.

Stewart CL, Gadi I \& Bhatt H 1994 Stem cells from primordial germ cells can re-enter the germ line. Developmental Biology 161 $626-628$.

Surani MA 2001 Reprogramming of genome function through epigenetic inheritance. Nature 414 122-128.

Surani MA, Barton SC \& Norris ML 1984 Development of reconstituted mouse eggs suggests imprinting of the genome during gametogenesis. Nature 308 548-550.

Sutherland JE \& Costa M 2003 Epigenetics and the environment. Annals of the New York Academy of Sciences 983 151-160.

Szyf M 2003 DNA methylation and cancer therapy. Drug Resistance Updates $6341-353$.

Tada M, Tada T, Lefebvre L, Barton SC \& Surani MA 1997 Embryonic germ cells induce epigenetic reprogramming of somatic nucleus in hybrid cells. EMBO Journal 16 6510-6520.
Tada T, Tada M, Hilton K, Barton SC, Sado T, Takagi N \& Surani MA 1998 Epigenotype switching of imprintable loci in embryonic germ cells. Development Genes and Evolution 207 551-561.

Tam PP \& Snow MH 1981 Proliferation and migration of primordial germ cells during compensatory growth in mouse embryos. Journal of Embryology and Experimental Morphology 64 133-147.

Toyooka Y, Tsunekawa N, Akasu R \& Noce T 2003 Embryonic stem cells can form germ cells in vitro. PNAS 100 11457-11462.

Turnpenny L, Brickwood S, Spalluto CM, Piper K, Cameron IT, Wilson DI \& Hanley NA 2003 Derivation of human embryonic germ cells: an alternative source of pluripotent stem cells. Stem Cells 21 598-609.

Ueda T, Abe K, Miura A, Yuzuriha M, Zubair M, Noguchi M, Niwa K, Kawase $Y$, Kono T, Matsuda $Y$, Fujimoto $H$, Shibata $H$, Hayashizaki Y \& Sasaki H 2000 The paternal methylation imprint of the mouse $\mathrm{H} 19$ locus is acquired in the gonocyte stage during foetal testis development. Genes to Cells 5 649-659.

Walsh CP, Chaillet JR \& Bestor TH 1998 Transcription of IAP endogenous retroviruses is constrained by cytosine methylation. Nature Genetics 20 116-117.

Walter J \& Paulsen M 2003 Imprinting and disease. Seminars in Cell and Developmental Biology 14 101-110.

Waterland RA \& Jirtle RL 2003 Transposable elements: targets for early nutritional effects on epigenetic gene regulation. Molecular and Cellular Biology 23 5293-5300.

Weksberg R, Smith AC, Squire J \& Sadowski P 2003 Beckwith-Wiedemann syndrome demonstrates a role for epigenetic control of normal development. Human Molecular Genetics 12 R61-R68.

Yamazaki Y, Mann MR, Lee SS, Marh J, McCarrey JR, Yanagimachi R \& Bartolomei MS 2003 Reprogramming of primordial germ cells begins before migration into the genital ridge, making these cells inadequate donors for reproductive cloning. PNAS $\mathbf{1 0 0}$ 12207-12212.

Yoder JA, Walsh CP \& Bestor TH 1997 Cytosine methylation and the ecology of intragenomic parasites. Trends in Genetics 13 335-340.

Young LE 2001 Imprinting of genes and the Barker hypothesis. Twin Research 4 307-317.

Young LE 2003 Scientific hazards of human reproductive 'cloning'. Human Fertility 6 59-63.

Young LE \& Fairburn HR 2000 Improving the safety of embryo technologies: possible role of genomic imprinting. Theriogenology $\mathbf{5 3}$ 627-648.

Young LE \& Beaujean N 2004 DNA methylation in the preimplantation embryo: the differing stories of the mouse and sheep. Animal Reproduction Science 82 61-78.

Young LE, Fernandes K, McEvoy TG, Butterwith SC, Gutierrez CG, Carolan C, Broadbent PJ, Robinson JJ, Wilmut I \& Sinclair KD 2001 Epigenetic change in IGF2R is associated with fetal overgrowth after sheep embryo culture. Nature Genetics 27 153-154.

Young LE, Rees WD \& Sinclair KD 2004 Heritable DNA methylation changes as a means to induce nutritional programming in the preimplantation embryo. In Frontiers in Nutrition Science, No 2: Programming in the Preimplantation Embryo, Ed SC LangleyEvans. pp 333-351. Oxfordshire, UK: CABI Publishing.

Zalduendo M-M, Boyano D, Feil R, Andollo N \& Arechaga J 2001 Methylation and chromatin conformation in the U2af1-rs1 imprinted gene in the male germ cell line. Developmental Biology 45 S145-S146.

Received 5 July 2004

First decision 13 August 2004

Revised manuscript received 25 October 2004

Accepted 4 November 2004 